\title{
The Study of a City in the Schools of that City
}

\section{John Cotton Dana}

To cite this article: John Cotton Dana (1911) The Study of a City in the Schools of that City, The Pedagogical Seminary, 18:3, 329-335, DOI: 10.1080/08919402.1911.10532792

To link to this article: http://dx.doi.org/10.1080/08919402.1911.10532792

Published online: 30 Aug 2012.

Submit your article to this journal 2

III Article views: 3

Q View related articles $\sqsubset$ 


\section{THE STUDY OF A CITY IN THE SCHOOLS OF THAT CITY}

\section{By John Cotton Dana}

There are many plans for improving the government of cities; the best is that which simply asks that the city's citizens be educated. Referendum, initiative, recall, charter revision, commission government, new laws, civic leagues, reform movements and all the many other plans for making our cities more wisely and more honestly governed, and therefore cleaner, more healthful, more beautiful, and more desirable for business and more attractive as homes-these may help a little, temporarily, here and there; but genuine and permanent improvement can come only through improvement in the character and intelligence of the citizens. Golden conduct cannot come from leaden instincts, says the philosopher, and the wayfaring man sees that the philosopher is right.

The educational process is slow. A city's educational work can be as good as the people of the city wish it to be, and no better; and the people of a city can wish only for that kind of education and will demand only that kind and will tolerate only that kind which conforms to their own outlook, ability and prejudice. The stream cannot rise above its fountain; and the education of a city like the government of a city is just what the ability of its people entitles them to. The elders having but little wisdom can pass on but little to the next generation.

There are a few things, however, in which the elders can make their children wiser than themselves. On one of these things the public schools and the public library of Newark, N. J., have spent much time and energy in recent years. I refer to the study of their own city by the children of the city in the schools of the city. Newark is the first city in this country, so far as I know, in which this study has been taken taken up broadly and seriously, with a quite definite purpose and with quite elaborate and carefully designed apparatus.

The story of it is briefly as follows:

The library, about eight years ago, sought for literature interesting to young people on the history, population, government, industries and other features of Newark. Such material 
was needed to lend to young visitors to the children's room. Very little was found, and that little was scattered and fragmentary. All that was found was addressed to adults, not to young people. Finally the library decided to publish a little local material of its own. Mr. F. J. Urquhart, one of the editors of the Newark Sunday Call, was asked to write three short stories of Newark's origin and development and these the library issued in small pamphlets, one each winter, as they were prepared. They were lent to young people; were given or lent to teachers, single copies or in packages of 25 , for use as readers; and were sold at 5 cents each.

In the three years during which these three pamphlets were being published, partly on account of their publication and use, partly on account of the continued promotion of the subject by the library, chiefly perhaps on account of that growth in civic pride which is now going on in most cities, interest in Newark study in the schools steadily increased. In the curriculum here and there were placed, for the most part at the suggestion of the library, instructions and suggestions to teachers about Newark geography, history, industries and institutions as topics for study, for essays and talks. School work upon these topics led many more children than before to come to the library for Newark information.

No city in the country seems to be equipped with such statements of its own life and varied activities as will interest or instruct its young people. Certainly Newark is not. Newark information in this line was sought for by the library in newspapers, books, city reports and other sources; was gathered, clipped, summarized, re-written, classified and made easily accessible. Short accounts were compiled of Streets, Parks, Trees, Water Supply, Sewage, Health Department, Fire Department, Police Department, Schools, Hospitals, and many other factors and aspects of the city's life. These "Newark Study" stories, usually between 500 and I,200 words in length, were duplicated to the extent of hundreds of copies and were lent or given to teachers and children on request.

Pictures were gathered of noteworthy Newark citizens, of historic events and scenes, historic houses, public buildings, notable trees, parks, streets, and these with maps old and new and many other things were mounted on cards of uniform size, classified and arranged for easy examination. These pictures also were lent on request to teachers and pupils.

Each year on Newark Day, May 17, a modest exhibit of all kinds of print and pictures, etc., about Newark was installed in the library and was usually visited by several thousand children, often with their teachers. 
This plan for making good citizens by giving the children a knowledge of their city and a consequent interest in it met with approval wherever and whenever it was discussed. . It appealed especially to business men, as was shown by the action of the City's Board of Trade concerning it. That body not only heartily endorsed the work; but also paid for printing an extra thousand for free distribution of one of the history pamphlets.

About two years ago the Board of Education asked the author of the three little pamphlets, published by the library, on the Story of Newark, called respectively "Early Days," "Awakening" and "Progress," to revise them, cast them into one continuous narrative and publish them in one volume, with maps, illustrations and index. Mr. Urquhart did this, and the volume appeared in attractive form under the title, "A Short History of Newark." In accordance with an agreement entered into before publication the Board of Education purchased at once 2,500 copies of this book, and later 2,500 more, and placed it on its approved list. This meant that any teacher interested in the subject, either on her own motion or at the suggestion of her principal, who wished to use the book as a reader or as a supplement to her work in American history, could secure as many copies as she needed.

Not long after this the Board of Education called for a meeting in the public library of teachers, principals and citizens interested in promoting good citizenship. At this meeting, maps, charts, pictures, diagrams, etc., were shown on the walls, and leaflets, notes and books were distributed for examination, all suggesting ways and means of displaying teaching and using as a basis of talks, readings and essays, some of the more interesting and important facts about the city.

Soon after this meeting the Board of Education ordered made a hundred large maps of the city for school use. These are more than nine feet square, and are mounted on rollers. They show streets, parks, public buildings, railroads, trolley lines, ward boundaries and many other things all distinguished by appropriate marks and colors. They can be read easily across a school-room. I believe no city in the country has ever before caused to be made and put before its children an adequate map of the place in which they live. Maps of North America, Asia, Europe, the World, are common enough; and occasionally one finds in a school an antiquated map of one's own state. But a large, accurate, complete and interesting map of one's own city-this is something unknown in the equipment of a city's schools. 
While these maps were being made,-and they were drawn and colored for the one purpose of making their town's area, form, character, etc., interesting and easily understood by the young-another small map was also designed. This is about twelve inches square, shows only a few of the streets, only one or two of the railroads and only a suggestion here and there of other details. It is in black only, is printed on thin writing paper, is issued in thousands of copies and is put up in pads of roo for easy handling. This map is used for class work. The teacher asks her pupils, each having a copy of this skeleton map, to add to it such details as she may select to form any special lesson:- railroads, trolley lines, school houses, parks, hospitals, fire-houses, etc. They will thus furnish the basis for exercises in drawing, map making, geography and other studies, all with direct relation to the city of which they are to become citizens.

Meanwhile the superintendent of schools and his assistant were revising those parts of the course of study which could be most easily made to include references to the city, especially those having to do with Public Hygiene, Civics, History and Geography. Included in these are brief discussions of many subjects like tuberculosis, pure milk, a safe and sane fourth of July, water supply, sewage disposal and paving and care of streets, designed to suggest to the teachers the lines their work may take, topics which pupils may look up in the library and consider in brief compositions. They include also, and special emphasis is laid upon these, suggestions of things, which may be done by the pupils themselves in helping to take care of their own city, either individually or in organized groups, such as care of trees, protection of birds, and cleaning of the school yard. It is essential, of course, not only that the children know how a city may be made more beautiful and attractive, but also that they apply some of this knowledge to useful ends.

This "Newark and the City Arts" portion of the course of study of the schools is published complete in one volume. It is also issued in several parts, each containing so much of the course as has to do with a particular grade, that each teacher may have her Newark work all in one group.

In uniform style with the course of study are published about forty different leaflets of one to eight pages each. These are for the use of pupils as well as teachers. They are largely revisions of the multigraphed sheets already alluded to as having been compiled or copied and issued by the library several years ago. They now appear printed in attractive form.

They cover the following among many other subjects: Hospitals, Public Buildings, Streets, Industries, Water Supply, 
Free Public Library, Police Department, Public health, Regulation of explosives Ordinance, Street lighting Ordinances, Littering streets Ordinance, Shade Tree Ordinances.

These bear two series of page numbers, that for each leaflet and that for the entire series of which each forms a part. For teacher's desk use they will be bound in one volume; for use by the pupils as reading lessons or in studying special topics they appear singly and are printed in large quantities. They are written in plain and simple language, and of course do not include many details.

An index to the course of study and the leaflets and a guide to sources of information, compiled by the library, completes the printed material now in use. This was formed by taking from the course of study, from the leaflets and from the simpler books on Newark history, city life and public hygiene all words and phrases representing topics' which can well be used by teachers as subjects of study, talk and discussion, as questions for debate and as subjects for inquiry at the library and for brief compositions. These words and phrases number more than 250. A few typical ones are: Defectives and dependents; Diphtheria and antitoxin, see Epidemics; Dispensaries; Education, cost of to State; Elections; Excise Commission; Expectoration; Explosives; Factories; Franchises; Garbage, Disposal of, see Waste.

After each of these topics, as it appears in the list, is given a list of references to sources of information thereon. These sources include the course of study itself, the subsidiary leaflets, the maps of the city, the reports of the city's many deparments and the books, pamphlets, charts, diagrams and pictures found in the public library.

Summarizing these helps to the study of Newark and the City Arts by the children of the city they are:

I. Formal courses of study with definite instructions as to work in the several grades in Newark History, Civil Government, Geography, and Public Hygiene.

2. An index to this course and to allied material.

3. References in this index to sources of information and suggestions on all Newark topics.

4. Leaflets descriptive of Newark's History, Population, Institutions, Laws and Customs, etc.

5. A Short History of Newark.

6. Books, Reports, Pamphlets, Clippings and Pictures relating to Newark in the Public Library.

In the past year this study of the city has been taken up in the high school. For this work tentative courses have been made adapted to pupils of high school age and such topics as the City Street and the Commission form of Government 
have been considered. Thus these courses will ultimately cover all of the four high school years and will supplement and carry on the work in the lower grades.

The very simple theory on which the work described has been laid out and carried on may be briefly summarized thus:

To the making of the good citizen go two fundamentals, intelligence and sympathy. The intelligence should be as broad and deep as each individual's capacity and opportunity permit him to make it. It may cover as many other subjects of every conceivable kind as the taste and circumstances of each individual may dictate; one subject it must cover if it is to be of service in making of its possessors a good citizen, and that subject is the citizen's own village, town or city, his own country and his own state. Confining the argument to city citizenship only, it is evident that that knowledge of his own city which forms one of the fundamentals of good citizenship includes in its objects much more than is included in the term civics or government. Indeed, knowledge of city government, while very desirable in a citizen, is a far less essential element in fashioning one into a good citizen than knowledge of the city's people, their intelligence, character and tendencies; its working conditions, of climate, topography, soil, and relation to other communities; its resources in stored wealth, in water power, lines of communications, houses, schools, factories, shops and public buildings; its improvements in water supply, sewage system, paving, parks and trees; its objects of interest and attraction, natural, artificial and historic; its self-supporting and elevating abilities acquired through the efficiency of its governmental and voluntary organizations, like fire departments, police departments, health departments, hospitals, churches, banks, libraries, museums, and all civic, social, charitable and benevolent institutions.

It seems needless to carry the enumeration further. It is evident enough that some acquaintance with these objects, movements and creations within one's own city is absolutely essential to one who would practice the art of citizenship wisely. Without such knowledge one cannot even cast his ballot intelligently once each year, and, what is of vastly more importance, cannot so conduct himself, hour by hour and day by day the whole year through, as to make his life helpful to his fellows.

I say this is evident enough, and I am sure most persons will agree with me, and I am also sure that most persons will be surprised to learn that not in any village, town or city of this country is this self-evident fact, about the fundamental importance in making good citizens of knowledge of one's own 
community, recognized in more than the slightest degree in the work of the public schools.

Of knowledge of alien things there is abundant mention and on the acquisition of that knowledge there is ceaseless insistence; but insistence on acquaintance with one's own community-such acquaintance as I have suggested with such facts as I have mentioned,- of this there is but the briefest mention and that only here and there.

Not only is it true that knowledge of facts about one's city is essential to good citizenship, it is also true that these facts furnish some of the best possible material on which to train the young.

History, geography, commercial geography, civil government, public hygiene, literature, composition, climate, geology, natural history and many other subjects may be made more valuable, more impressive, more easily understood and more attractive if concrete illustrations for them are found in one's own city.

Again it seems unnecessary to labor the point. At the schoolroom door are found the things which can and should illustrate the text-books on many subjects. It is said that thus to use one's own environment as a tool in formal discipline calls for two things, neither of which is at hand, to wit, elaborate text-books written to that environment and teachers able to use both book and environment; the answer is that quite a wide use of one's own city as a basis of much elementary educational work does not call for either of these things, as the experience of Newark shows.

The experience of Newark has not yet been sufficient to prove that familiar knowledge of the character and daily life of one's own city, and daily practice in making that character better and that life cleaner and more wholesome, are of all knowledges and all habits the most effective in making good citizens. But the mere statement of the theory seems to make it worth while to test it thoroughly. 